\title{
DO PROPERTIES AND SPECIES OF WEED SEEDS AFFECT THEIR CONSUMPTION BY CARABID BEETLES?
}

\author{
Hana Foffoví ${ }^{1,2}{ }^{,}$David A. Bohan ${ }^{3}$ and Pavel Saska ${ }^{1}$ \\ ${ }^{1}$ Crop Research Institute, Functional Diversity in Agro-Ecosystems \\ Drnovská 507, 16106 Praha 6 - Ruzyně, Czech Republic \\ E-mail: foffova@vurv.cz, https://orcid.org/0000-0001-5528-7211 \\ saska@vurv.cz; https://orcid.org/0000-0003-1397-2987 \\ ${ }^{2}$ Czech University of Life Sciences, Faculty of Environmental Sciences, Department of Ecology \\ Kamýcká 129, 16500 Praha 6 - Suchdol, Czech Republic \\ ${ }^{3}$ Agroécologie, AgroSup Dijon, INRAe, Université de Bourgogne Franche-Comté \\ F-21000 Dijon, France; E-mail: David.Bohan@inrae.fr; https://orcid.org/0000-0001-5656-775X
}

Seed predators are an integral part of agroecosystems, where they can reduce the populations of weeds. The preference of predators for seeds and the observed predation rate may be affected by the properties of seeds (e.g. taxonomy, chemical composition, physical defence). In this work, we focused on seed consumption of Taraxacum officinale Web. and Stellaria media (L.) Vill., from France and the Czech Republic, by three species of ground beetle that are seed predators (Coleoptera: Carabidae): Poecilus cupreus (L.), Pterostichus melanarius (Illiger) and Anchomenus dorsalis (Pontoppidan). The seed species were offered in arenas, simultaneously, under three different experimental manipulations of moisture and seed coat conditions: dry and intact, water-imbibed and intact, and water-imbibed with a damaged seed coat. Seed consumption was checked after 0.5, 1, 2, 24, and $48 \mathrm{hrs}$ of exposure. Anchomenus dorsalis largely refused to feed on seeds. Taraxacum officinale seeds with damaged coats were most preferred by the remaining two species of carabids. The consumption by $P$. cupreus of T. officinale seeds with damaged coats increased from $0.18 \%$ after $0.5 \mathrm{hrs}$ to $83.83 \%$ after $48 \mathrm{hrs}$, and by P. melanarius from $13.76 \%$ after $0.5 \mathrm{hrs}$ to $76.77 \%$ after $48 \mathrm{hrs}$. Seeds of $S$. media were consumed less. There was a significant difference in consumption rates due to the country of origin of the seeds, but there were no differences between the carabid sexes. That carabids preferred water-imbibed and damaged seeds may suggest an involvement of olfactory clues in the seed selection process, and/or shorter seed-handling times.

Keywords: carabid beetle, weed seeds, preference, imbibed seeds, seed predator, granivory.

\section{INTRODUCTION}

Ground beetles are one of the most important seed predator groups in agroecosystems (Tooley \& Brust 2002, Gallandt et al. 2005, Honek et al. 2005,). Seeds constitute a vital part of the diet for both adults and larvae (SAsKA 2005, 2008, Klimes \& SASKA 2010). Seed predators can remove 18 to $70 \%$ of seeds produced annually (WESTERMAN et al. 2003) thus they can reduce the input of seeds into the soil bank in arable fields (BoHAN et al. 2011). Numerous factors affect seed predation and selection by carabid beetles, such as seed size 
(Forsythe 1983, Acorn \& Ball 1991), seed mass (Honek et al. 2007), seed coat thickness (Lundgren \& Rosentrater 2007), chemical composition (Bewley \& Black 1982, JANZEN 1982, Hulme 1996), time after ripening of the seeds (SASKA et al. 2019a), the hardness of seeds (VAN Der Meij \& Bout 2000) and state of seed imbibition (LAw \& Gallagher 2015), amongst others. One understudied effect is the geographical origin of the seed. Both physical and chemical properties of seeds may vary among locations (WIDMER et al. 2007, He et al. 2020), which may influence the seed choice by granivores (HoneK et al. 2011).

The attributes of the ground beetle predator may also affect seed consumption. There is a positive correlation between the mass of the carabid and the mass of the most preferred seeds (НоNEK et al. 2006, SASKA et al. 2019b). The sex of the carabid also influences seed consumption, with females consuming more seeds than males (Marshall \& Moonen 2002, Sasakawa 2010, Saska et al. 2010, KulKarni et al. 2015), probably because they require more energy for reproduction. Dietary preferences are also influenced by the evolutionary history of carabids: species of the tribe Zabrini prefer seeds of Asteraceae, while those of the tribe Harpalini may feed upon seeds of the Violaceae and other Asteraceae usually not selected by the Zabrini (НоNeK et al. 2007, SASKA et al. 2019b).

Carabids seem to use olfactory (LAw \& GaLlagher 2015) and tactile cues (KiELty et al. 1996) when searching for seeds. The type or amount of chemical cues released from seeds might be affected by conditions of the seeds, e.g. the state of the seed coat or the levels of imbibition. Many seed predators are not able to detect seeds with an impermeable coat, most likely because chemical cues are not released from the seed (VANDer WaLl 1998). Beetles appear to prefer water-imbibed seeds over the dry seeds (KULKARNi et al. 2016, 2017) because the olfactory cues of the previous are stronger and the handling time of these seeds is also shorter (personal observation).

There is a lack of information about the preferences of carabids for seed species in interaction with water-imbibed seeds or seeds with a damaged seed coat. In this study, we conducted a multiple-choice test to determine the preference of the three carabid species: Pterostichus melanarius, Poecilus cupreus and Anchomenus dorsalis. Although the representatives of the genera Pterostichus, Poecilus and Anchomenus are commonly regarded as predominantly carnivorous species, they have been frequently observed to consume seeds (Goldschmidt \& Toft 1997, Honek et al. 2003, Hurst \& Doberski 2003, Deroulers \& Bretagnolle 2019). The presence of plant DNA in carabid regurgitates of $P$. melanarius and P. rufipes was found to be substantial $(>70 \%$ of individuals) and independent of carabid species, sex, region and the time of sampling (Frei et al. 2019). In particular, P. melanarius has been described as a generalist predator (BoHAN et al. 2000, LANGAN et al. 2004, BARGMANN et al. 2016), but this species also consumes weed seeds (Tooley et al. 1999, HoneK et al. 2003). P. melanarius has been found to readily accept fresh, dry and im- 
bibed seeds of Brassica napus (Koprdova et al. 2012). On average, P. melanarius consumed three seeds of $S$. media seeds in $48 \mathrm{hrs}$ in a cafeteria test (Tooley et al. 1999). P. cupreus is known as an omnivorous species (LöveI \& SUNDERLAND 1996, Honek et al. 2003, Bargmann et al. 2016, Saska et al. 2019b). Very little is known about seed consumption of $A$. dorsalis. This species consumed $1.7 \pm 1.4$ seeds of Capsella bursa-pastoris during a three days experiment (HoneK et al. 2003). Because it is one of the dominant species in European agroecosystems, the capacity of this species to eat seeds is worth exploring.

The preferences of the three different conditions of seeds (dry/intact, imbibed/intact and imbibed/damaged) were tested on three different species of carabids, separately for each sex. We expected: (i) carabid species-specific responses to particular species of seed; (ii) specific responses to the different seed conditions; (iii) sex-specific consumption; and (iv) that geographical origin of the seeds would affect consumption.

\section{MATERIAL AND METHODS}

\section{Ground beetles}

Three species of carabids were used in this study: Pterostichus melanarius, Poecilus cupreus and Anchomenus dorsalis. These species were selected because they are amongst the most abundant carabids in arable fields in France. The ground beetles were collected using pitfall traps from two field edges on the INRAe experimental farm near Dijon, France $\left(47.233^{\circ} \mathrm{N}, 5.097^{\circ} \mathrm{E}\right)$ between the end of September and October 2018. We used 160 trapped individuals of each species for the experiments. Beetle identification was made according to HŮRKA (1996). Carabids were starved for 3 days before the trial. The beetles were individually kept in plastic containers $(7.5 \mathrm{~cm}$ in diameter) covered with a lid at room temperature to standardise their hunger level (LundGren \& ROSENTRATER 2007) and water was provided by placing a wet cotton roll on the bottom.

\section{Seeds}

We used seeds of Taraxacum officinale (Asteraceae) and Stellaria media (Caryophyllaceae); species that have previously been used for experimentation with adults as well as larvae of carabid beetles (Honek et al. 2005, Saska 2008, Ретіт et al. 2014). The seeds of T. officinale are obconic achenes $2.5 \times 0.9 \mathrm{~mm}$ long on average (BoJNANsKÝ \& FARGAŠOvá 2007), and are rich in proteins (25.65\%), lipids $(27.86 \%)$ and carbohydrates $(23.05 \%)$ (BRETAGNOLLE et al. 2016). The seeds of $S$. media are round, ca. $1 \mathrm{~mm}$ diameter (BojnANsKÝ \& FARGAšová 2007), and have lower protein $(16.44 \%)$ and lipid (5.19\%) content than T. officinale, but are higher in carbohydrate (65.22\%) (BRETAGNOLle et al. 2016). Seeds from the Czech Republic (collected near to CRI, Prague, $50.086^{\circ} \mathrm{N}, 14.302^{\circ} \mathrm{E}$ ) and France (collected near to INRAe Dijon, $\left.47.316^{\circ} \mathrm{N}, 5.068^{\circ} \mathrm{E}\right)$ were used. All seeds were dried at room temperature $\left(22^{\circ} \mathrm{C}\right)$ for 4 weeks. Plant identification was made according to Кивát et al. (2002). 


\section{Experiment design}

The effects of seed species, conditions, location of origin and the sex of the beetles, and all interactions, on seed consumption by ground beetles, were tested in a multi-choice experiment. The experimental arenas consisted of Petri dishes $(14 \mathrm{~cm}$ in diameter) lined with moist filter paper on the bottom. Both species of seeds, T. officinale and S. media, were placed simultaneously in each arena. Three seed conditions were used: dry/intact, imbibed/ intact and imbibed/damaged. To assure that the dry treatment seeds remain dry at the time of exposure, they were placed into the arena immediately before the start of the trial. The water-imbibed seeds were left to soak on wet filter paper for $24 \mathrm{hrs}$ before the start of the trial. The imbibed/damaged seeds were first imbibed on filter paper for $24 \mathrm{hrs}$, after which a small hole was made through the seed coat using an entomological pin number $0(0.35 \mathrm{~mm}$ in diameter), so the seeds remained viable (confirmed by conducting a parallel germination test on a subset of 20 seeds per species and country; data not shown). Each condition was replicated five times per dish, so 30 seeds were presented at a time (Fig. 1). The French and Czech seeds were examined separately. The photoperiod was set for $10 \mathrm{hrs}$ light/14 hrs dark and constant temperature of $17^{\circ} \mathrm{C}$, in order to prevent any temperature effect on seed consumption (SASKA et al. 2010). The experiment was conducted from the end of October to the beginning of December 2018. Individual beetles were released into arenas and the remaining seeds were counted after $0.5,1,2,24$, and $48 \mathrm{hrs}$. Any seed that was more than half-eaten was considered eaten and removed, as were the empty seed coats.

\section{Statistical analysis}

The statistical analysis was performed by generalised mixed effects models in $\mathrm{R}$ version 3.5.3 (R Core Team) using the package glmmTMB (ВRоокs et al. 2017). Since A. dorsalis ate very few seeds (a total of 89 out of the 4800 seeds offered), the data for this species were not analysed. The preferences of $P$. melanarius and $P$. cupreus were tested separately. Since the data contained a high proportion of zeros, we fitted models using the binomial and beta-binomial distributions, with or without terms that accounted for zero-inflation, and with or without arena as a random factor (because the consumptions of different seed conditions within the same arena were not independent from each other). Models based on beta-binomial distribution without the zero-inflation term and with random effect were superior (justified by the change in Akaike Information Criterion). As the preferred models did not show any signs of overdispersion and zero-inflation (checked using the DHARMa

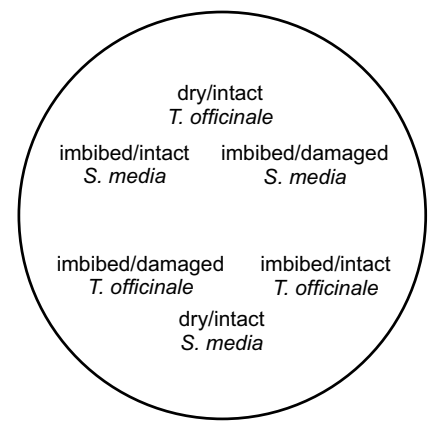

Fig. 1. Design of the testing arena 
package; HARTIG 2016), beta-binomial models were used in the subsequent steps of model simplification. Significance of individual terms in the models was assessed using the Anova function from the car package (Fox \& WEISBERg 2019).

\section{RESULTS}

Seed consumption was affected by seeds species and conditions, and it varied between the carabid species (Table 1). For P. melanarius, seed preference was affected by seed conditions, species and geographical origin. There were also significant two- and three-way interactions between seed conditions and seed origin, and seed species, seed conditions and geographical origin (Table 2). Seeds of T. officinale were preferred more than S. media. Dry/intact seeds were consumed significantly less than imbibed/intact and imbibed/damaged seeds. The seeds from France were consumed significantly more than the Czech seeds. There was no effect of the sex of the beetle (Table 2).

Poecilus cupreus also preferred seeds of T. officinale. Dry/intact seeds were the least consumed seed conditions followed by imbibed/intact seeds. There was a significant interaction between seed species and seed conditions, as well between seed conditions and seed origin (Table 3). There was also no significant difference in consumption between the sexes of the beetles.

Table 1. The mean proportions (95\% confidence intervals) of consumed seeds by two species of carabids in $48 \mathrm{hrs}$.

\begin{tabular}{ccccc}
\hline Species of carabids/ & \multicolumn{2}{c}{ Stellaria media } & \multicolumn{2}{c}{ Taraxacum officinale } \\
\cline { 2 - 5 } Condition of seeds & France & Czech Republic & France & Czech Republic \\
\hline Pterostichus melanarius & & & & \\
Imbibed/damaged & 0.401 & 0.208 & 0.712 & 0.761 \\
& $(0.304,0.507)$ & $(0.142,0.294)$ & $(0.571,0.821)$ & $(0.629,0.856)$ \\
Dry/intact & 0.312 & 0.096 & 0.803 & 0.187 \\
& $(0.226,0.412)$ & $(0.059,0.151)$ & $(0.683,0.886)$ & $(0.107,0.304)$ \\
Imbibed/intact & 0.217 & 0.166 & 0.67 & 0.224 \\
& $(0.149,0.304)$ & $(0.110,0.241)$ & $(0.522,0.790)$ & $(0.132,0.353)$ \\
\hline Poecilus cupreus & & & & \\
Imbibed/damaged & 0.196 & 0.102 & 0.853 & 0.702 \\
& $(0.113,0.317)$ & $(0.054,0.187)$ & $(0.656,0.946)$ & $(0.456,0.868)$ \\
Dry/intact & 0.144 & 0.061 & 0.843 & 0.361 \\
& $(0.080,0.245)$ & $(0.030,0.119)$ & $(0.642,0.942)$ & $(0.168,0.612)$ \\
Imbibed/intact & 0.135 & 0.078 & 0.751 & 0.241 \\
& $(0.075,0.232)$ & $(0.039,0.149)$ & $(0.506,0.899)$ & $(0.101,0.474)$ \\
\hline
\end{tabular}


Table 2. The minimum model for the seed preference of Pterostichus melanarius determined after 48 hrs. Generalised mixed-effects model with beta-binomial distribution was used.

\begin{tabular}{lccc}
\hline Variables & $\chi^{2}$ & Df & P \\
\hline Seed species & 181.872 & 1 & $<0.001$ \\
Seed conditions & 45.223 & 2 & $<0.001$ \\
Seed origin & 14.207 & 1 & $<0.001$ \\
Seed species $\times$ Seed conditions & 2.799 & 2 & 0.246 \\
Seed species $\times$ Seed origin & 3.421 & 1 & 0.064 \\
Seed conditions $\times$ Seed origin & 36.934 & 2 & $<0.001$ \\
Seed species $\times$ Seed conditions $\times$ Seed origin & 26.784 & 2 & $<0.001$ \\
\hline
\end{tabular}

The cumulative proportion of seeds consumed increased over time (Fig. 2). The most preferred seeds were those of T. officinale with imbibed/damaged seed coat. The consumption of these seeds differed between carabid species: P. cupreus consumed $0.18 \%$ of the seeds after $0.5 \mathrm{hrs}$, while P. melanarius consumed $13.76 \%$ of the seeds over the same time period. The consumption of these seeds, regardless of seed origin, gradually increased and P. cupreus and P. melanarius consumed $83.83 \%$ and $76.77 \%$ of seeds after $48 \mathrm{hrs}$, respectively.

- after $0.5 \mathrm{~h} \quad \circ \operatorname{after} 1 \mathrm{~h} \quad \circ$ after $2 \mathrm{~h} \quad \bullet$ after $24 \mathrm{~h} \quad \bullet$ after $48 \mathrm{~h}$
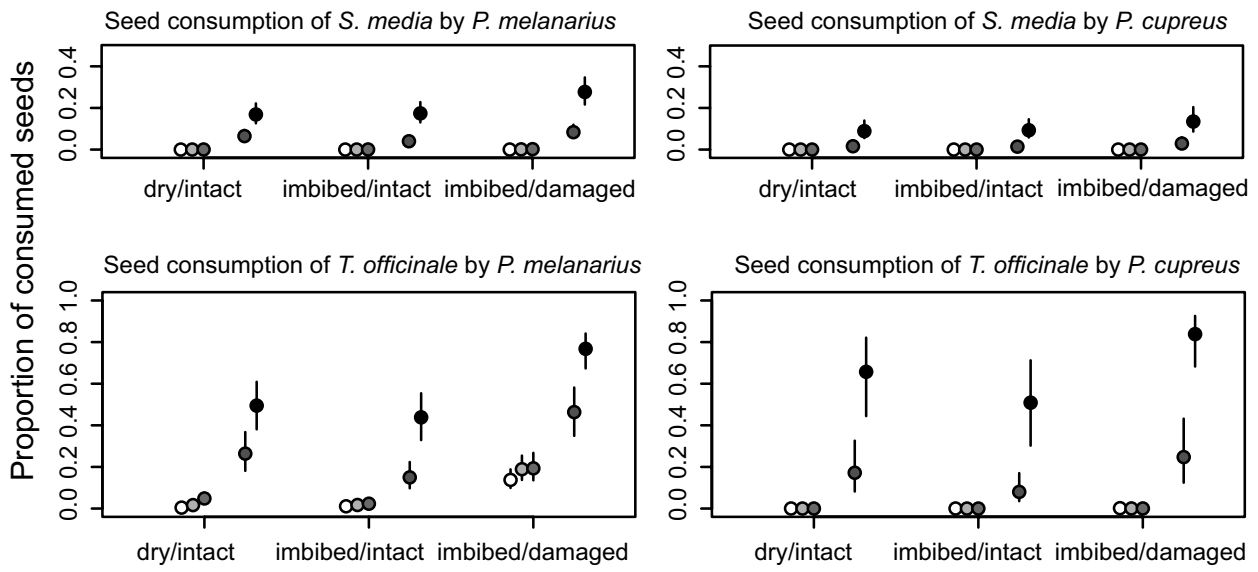

Seed condition

Fig. 2. Average cumulative consumption rate by carabids during the time of $0.5,1,2,24$, and $48 \mathrm{hrs}$. Each point represents the mean consumption, and the vertical bars represent $95 \%$ confidence interval. Points within particular seed condition are spaced based on log(time of exposure). Note that the ranges of y-axis differ between the top and bottom panels. 
Table 3. The minimum model for the seed preference of Poecilus cupreus determined after $48 \mathrm{hrs}$. Generalised mixed-effects model with beta-binomial distribution was used.

\begin{tabular}{lrcc}
\hline Variables & \multicolumn{1}{c}{$\chi^{2}$} & Df & P \\
\hline Seed species & 293.469 & 1 & $<0.001$ \\
Seed conditions & 26.124 & 2 & $<0.001$ \\
Seed origin & 4.347 & 1 & 0.037 \\
Seed species $\times$ Seed conditions & 7.039 & 2 & 0.029 \\
Seed conditions $\times$ Seed origin & 6.462 & 2 & 0.039 \\
\hline
\end{tabular}

The seed consumption of S. media was lower than the consumption of T. officinale. The most preferred seeds of the $S$. media sets were the imbibed/damaged conditions. Consumption after $48 \mathrm{hrs,} \mathrm{irrespective} \mathrm{of} \mathrm{the} \mathrm{origin} \mathrm{of} \mathrm{the} \mathrm{seeds,}$ was $13.46 \%$ of seeds for P. cupreus, and $27.69 \%$ of seeds for P. melanarius.

\section{DISCUSSION}

In this study, the seed preferences of two omnivorous carabid species were found to depend on the seed species, conditions and the geographical origin of the seeds. Pterostichus melanarius and Poecilus cupreus consumed a rather high number of seeds of Taraxacum officinale in our study, and both consumed more of the water-imbibed than dry seeds. In other studies, carabids also made significant preference choices for imbibed seeds (Hurst \& DobersKi 2003, KulKarni et al. 2016).

Several mechanisms could explain why the dry and unimbibed seeds were less consumed by carabids (Fig. 2). These seeds release less olfactory volatiles than those that are imbibed (PAULSEN et al. 2013) and more attractive to predators. Dry and unimbibed seeds may also deter seed predators (CARDINA et al. 1996), because of the chemical compounds in the seed coat. Alternatively, it may be that the effect of imbibition on the hardness or thickness of the seed coat (LundGren \& Rosentrater 2007), is to soften the seed coat making penetration by the carabids relatively easier. The seeds of $S$. media have stronger and harder seed coats than $T$. officinale, which may partly explain the higher predation of seeds of T. officinale observed. Another mechanism may be related to the chemical properties of seeds which are not changed during imbibition, such as the volatile compounds (PAUlsen et al. 2013), waxes and other secondary metabolites that are present (JANZEN 1982). Both mechanisms may also explain the increase in consumption in the case of imbibed seeds with damaged coats. It is possible that the handling time of these seeds by the carabids was shorter (MiKHEEv \& WANZENBöcK 2010), although this was not measured in our study. 
On average, after one day of seed exposure, consumption by $P$. melanarius was 3.44 seeds of T. officinale and 1.9 seeds of $S$. media, and that by P. cupreus was 2.46 seeds of $T$. officinale and 0.3 seeds of $S$. media. The daily consumption of T. officinale is lower than observed by (Ретіт et al. 2014). The consumption rates observed here could be negatively affected by the relatively late time of the year that the experiment was conducted in October. Although the experiment was carried out in the laboratory, the beetles were collected in the field near the end of their period of seasonal activity. The predation rate has been found both to be low in the winter months (CARDina et al. 1996) and to decline from late summer (HoneK et al. 2003). The season of the experiment could also affect the consumption by the different beetle sexes (HoneK et al. 2006) because in the autumn females no longer need energy for reproduction.

Current information about carabid selection for seeds with different geographical origin is limited. HoneK et al. (2011) demonstrated that the locale of seed origin played an important role in preferences of carabids. In our study, the origin of the seed significantly affected seed consumption and preferences by both species of carabids (Tables $1 \& 2$ ). The French beetles used in our study preferred French seeds; unfortunately, we could not make the same comparison with Czech beetles since these were not available at the time of the experiment. Differential consumption by origin might be explained by micro-species of plants (MogIE \& Ford 1988). Perhaps seeds from particular geographical regions differ e.g. in starch (WIDMER et al. 2007) or oil content (He et al. 2020) to which local carabids respond, and this aspect of seed-predator interaction deserves further attention.

Acknowledgements - This work was supported by the Czech Science Foundation grant \#17-00043S and Mobility MŠMT \#CZ.02.2.69/0.0/0.0/16_027/0008503.

\section{REFERENCES}

Acorn, J. H. \& BALL, G. E. (1991): The mandibles of some adult ground beetles - structure, function, and the evolution of herbivory (Coleoptera: Carabidae). - Canadian Journal of Zoology-Revue Canadienne De Zoologie 69: 638-650. https://doi.org/10.1139/z91-094

Bargmann, T., Heegaard, E., Hatteland, B. A., Chipperfield, J. D. \& Grytnes, J. A. (2016): Species trait selection along a prescribed fire chronosequence. - Insect Conservation and Diversity 9: 446-455. https://doi.org/10.1111/icad.12182

Bewley, J. D. \& Black, M. J. B. (1982): Physiology and biochemistry of seeds in relation to germination. - Springer-Verlag, Berlin, 375 pp. https://doi.org/10.1007/978-3-642-68643-6

Bohan, D. A., Bohan, A. C., Glen, D. M., Symondson, W. O. C., Wiltshire, C. W. \& Hughes, L. (2000): Spatial dynamics of predation by carabid beetles on slugs. - Journal of Animal Ecology 69: 367-379. https://doi.org/10.1046/j.1365-2656.2000.00399.x 
Bohan, D. A.; Boursault, A., Brooks, D. R. \& Petit, S. (2011): National-scale regulation of the weed seedbank by carabid predators. - Journal of Applied Ecology 48: 888-898. https://doi.org/10.1111/j.1365-2664.2011.02008.x

BojnanskÝ, V. \& Fargašová, A. (2007): Atlas of seeds and fruits of Central and East European flora. - Springer, Netherlands, $1046 \mathrm{pp}$.

Bretagnolle, F., Matejicek, A., Gregoire, S., Reboud, X. \& Gaba, S. (2016): Determination of fatty acids content, global antioxidant activity and energy value of weed seeds from agricultural fields in France. - Weed Research 56: 78-95. https://doi.org/10.1111/wre.12188

Brooks, M. E., Kristensen, K., van Benthem, K. J., Magnusson, A., Berg, C. W., Nielsen, A., Skaug, H. J., Machler, M. \& Bolker, B. M. (2017): glmmTMB Balances speed and flexibility Among packages for zero-inflated generalized linear mixed modeling. $-R$ Journal 9: 378-400. https://doi.org/10.32614/RJ-2017-066

Cardina, J., Norquay, H. M., Stinner, B. R. \& McCartney, D. A. (1996): Postdispersal predation of velvetleaf (Abutilon theophrasti) seeds. - Weed Science 44: 534-539. https:// doi.org/10.1017/S0043174500094297

Deroulers, P. \& Bretagnolle, V. (2019): The consumption pattern of 28 species of carabid beetles (Carabidae) to a weed seed, Viola arvensis. - Bulletin of Entomological Research 109: 229-235. https://doi.org/10.1017/S0007485318000457

Forsythe, T. G. (1983): Locomotion in ground beetles (Coleoptera, Carabidae) - an interpretation of leg structure in functional terms. - Journal of Zoology 200: 493-507. https:// doi.org/10.1111/j.1469-7998.1983.tb02811.x

Fox, J. Weisberg, S. (2019): An R companion to applied regression. 3rd ed. - Sage, Thousand Oaks. https://socialsciences.mcmaster.ca/jfox/Books/Companion/

Frei, B., Guenay, Y., Bohan, D. A., Traugott, M. \& Wallinger, C. (2019): Molecular analysis indicates high levels of carabid weed seed consumption in cereal fields across Central Europe. - Journal of Pest Science 92: 935-942. https://doi.org/10.1007/s10340-019-01109-5

Gallandt, E. R., Molloy, T., Lynch, R. P. \& Drummond, F. A. (2005): Effect of cover-cropping systems on invertebrate seed predation. - Weed Science 53: 69-76. https://doi. org/10.1614/WS-04-095R

Goldschmidt, H. \& ToFt, S. (1997): Variable degrees of granivory and phytophagy in insectivorous carabid beetles. - Pedobiologia 41: 521-525.

HARTIG, F. (2016): DHARMa: residual diagnostics for hierarchical (multi-level/mixed) regression models. $R$ package version 0.1. 0. - CRAN / GitHub

He, C. J., Li, Z. Y., Liu, H. X., Zhang, H. N., Wang, L. Y. \& Chen, H. (2020): Chemical compositions and antioxidant activity of adlay seed (Coix lachryma-jobi L.) oil extracted from four main producing areas in China. - Journal of Food Science 85: 123-131. https:// doi.org/10.1111/1750-3841.14982

Honek, A., Martinkova, Z. \& Jarosik, V. (2003): Ground beetles (Carabidae) as seed predators. - European Journal of Entomology 100: 531-544. https://doi.org/10.14411/eje.2003.081

Honek, A., Martinkova, Z. \& SAska, P. (2005): Post-dispersal predation of Taraxacum officinale (dandelion) seed. - Journal of Ecology 93: 345-352. https://doi.org/10.1111/ j.1365-2745.2005.00987.x

Honek, A., Martinkova, Z. \& SAska, P. (2011): Effect of size, taxonomic affiliation and geographic origin of dandelion (Taraxacum agg.) seeds on predation by ground beetles (Carabidae, Coleoptera). - Basic and Applied Ecology 12: 89-96. https://doi. org/10.1016/j.baae.2010.11.003 
Honek, A., Martinkova, Z., Saska, P. \& Pekar, S. (2007): Size and taxonomic constraints determine the seed preferences of Carabidae (Coleoptera). - Basic and Applied Ecology 8: 343-353. https://doi.org/10.1016/j.baae.2006.07.002

Honek, A., SAska, P. \& Martinkova, Z. (2006): Seasonal variation in seed predation by adult carabid beetles. - Entomologia Experimentalis et Applicata 118: 157-162. https:// doi.org/10.1111/j.1570-7458.2006.00376.x

Hulme, P. E. (1996): Herbivory, plant regeneration, and species coexistence. - Journal of Ecology 84: 609-615. https://doi.org/10.2307/2261482

Hurst, C. \& Doberski, J. (2003): Wild flower seed predation by Pterostichus madidus (Carabidae : Coleoptera). - Annals of Applied Biology 142: 251-254. https://doi. org/10.1111/j.1744-7348.2003.tb00248.x

HŮRKA, K. (1996): Carabidae of the Czech and Slovak Republics. Carabidae České a Slovenské republiky. - Kabourek, Zlín, Czech Republic, 565 pp.

JANZEN, D. H. (1971): Seed predation by animals. - Annual Review of Ecology and Systematics 2: 465-492. https://doi.org/10.1146/annurev.es.02.110171.002341

Kielty, J. P., Allenwilliams, L. J., Underwood, N. \& Eastwood, E. A. (1996): Behavioral responses of three species of ground beetle (Coleoptera: Carabidae) to olfactory cues associated with prey and habitat. - Journal of Insect Behavior 9: 237-250. https://doi. org/10.1007/BF02213868

Klimes, P. \& SAska, P. (2010): Larval and adult seed consumption affected by the degree of food specialization in Amara (Coleoptera: Carabidae). - Journal of Applied Entomology 134: 659-666. https://doi.org/10.1111/j.1439-0418.2009.01463.x

Koprdova, S., Saska, P., Honek, A. \& Martinkova, Z. (2012): Susceptibility of the early growth stages of volunteer oilseed rape to invertebrate predation. - Plant Protection Science 48: 44-50. https://doi.org/10.17221/22/2011-PPS

Kubát, K., Hrouda, L., Chrtek, J., Kaplan, Z., Kirschner \& ŠtěpáneK, J. (2002): Klič ke květeně. - Academia, Praha, 1172 pp.

Kulkarni, S. S., Dosdall, L. M., Spence, J. R. \& Willenborg, C. J. (2015): Depth of seed burial and gender influence weed seed predation by three species of ground beetle (Coleoptera: Carabidae). - Weed Science 63: 910-915. https://doi.org/10.1614/WS-D15-00080.1

Kulkarni, S. S., Dosdall, L. M., Spence, J. R. \& Willenborg, C. J. (2016): Brassicaceous weed seed predation by ground beetles (Coleoptera: Carabidae). - Weed Science 64: 294-302. https://doi.org/10.1614/WS-D-15-00069.1

Kulkarni, S. S., Dosdall, L. M., Spence, J. R. \& Willenborg, C. J. (2017): Seed detection and discrimination by ground beetles (Coleoptera: Carabidae) are associated with olfactory cues. - PLOS One 12: 11. https://doi.org/10.1371/journal.pone.0170593

Langan, A. M., Taylor, A. \& Wheater, C. P. (2004): Effects of metaldehyde and methiocarb on feeding preferences and survival of a slug predator (Pterostichus melanarius (F.): Carabidae, Pterostichini). - Journal of Applied Entomology 128: 51-55. https://doi. org/10.1046/j.1439-0418.2003.00801.x

Law, J. J. \& Gallagher, R. S. (2015): The role of imbibition on seed selection by Harpalus pensylvanicus. - Applied Soil Ecology 87: 118-124. https://doi.org/10.1016/j.apsoil.2014.11.015

Lövei, G. L. \& Sunderland, K. D. (1996): Ecology and behavior of ground beetles (Coleoptera: Carabidae). - Annual Review of Entomology 41: 231-256. https://doi.org/10.1146/ annurev.en.41.010196.001311 
Lundgren, J. G. \& Rosentrater, K. A. (2007): The strength of seeds and their destruction by granivorous insects. - Arthropod-Plant Interactions 1: 93-99. https://doi.org/10.1007/ s11829-007-9008-1

Marshall, E. J. R. \& Moonen, A. C. (2002): Field margins in northern Europe: their functions and interactions with agriculture. - Agriculture Ecosystems \& Environment 89: 5-21. https://doi.org/10.1016/s0167-8809(01)00315-2

Meij, M. A. A. van der \& Bout, R. G. (2000): Seed selection in the Java Sparrow (Padda oryzivora): preference and mechanical constraint. - Canadian Journal of Zoology-Revue Canadienne De Zoologie 78: 1668-1673. https://doi.org/10.1139/cjz-78-9-1668

Mikheev, V. N. \& Wanzenвöck, J. (2010): Diet changes in prey size selectivity in larvae of perch Perca fluviatilis. - Journal of Ichthyology 50: 1014-1020. https://doi.org/10.1134/ S0032945210110068

Mogie, M. \& Ford, H. (1988): Sexual and asexual Taraxacum species. - Biological Journal of the Linnean Society 35: 155-168. https://doi.org/10.1111/j.1095-8312.1988.tb00463.x

Paulsen, T. R., Colville, L., Kranner, I., Daws, M. I., Hogstedt, G., Vandvik, V. \& Thompson, K. (2013): Physical dormancy in seeds: a game of hide and seek? - New Phytologist 198: 496-503. https://doi.org/10.1111/nph.12191

Petit, S., Boursault, A. \& Bohan, D. A. (2014): Weed seed choice by carabid beetles (Coleoptera: Carabidae): Linking field measurements with laboratory diet assessments. - European Journal of Entomology 111: 615-620. https://doi.org/10.14411/eje.2014.086

SASAKAWA, K. (2010): Field observations of climbing behavior and seed predation by adult ground beetles (Coleoptera: Carabidae) in a lowland area of the temperate zone. Environmental Entomology 39: 1554-1560. https://doi.org/0.1603/EN10097

SASKA, P. (2005): Contrary food requirements of the larvae of two Curtonotus (Coleoptera: Carabidae: Amara) species. - Annals of Applied Biology 147: 139-144. https://doi. org/10.1111/j.1365-2745.2005.00987.x

SASKA, P. (2008): Effect of diet on the fecundity of three carabid beetles. - Physiological Entomology 33: 188-192. https://doi.org/10.1111/j.1365-3032.2008.00618.x

Saska, P., Honek, A., Foffova, H. \& Martinkova, Z. (2019a): Burial-induced changes in the seed preferences of carabid beetles (Coleoptera: Carabidae). - European Journal of Entomology 116: 133-140. https://doi.org/10.14411/eje.2019.015

Saska, P., Honek, A. \& Martinkova, Z. (2019b): Preferences of carabid beetles (Coleoptera: Carabidae) for herbaceous seeds. - Acta Zoologica Academiae Scientiarum Hungaricae 65: 57-76. https://doi.org/10.17109/AZH.65.Suppl.57.2019. https://doi.org/10.17109/ AZH.65.Suppl.57.2019

Saska, P., Martinkova, Z. \& HoneK, A. (2010): Temperature and rate of seed consumption by ground beetles (Carabidae). - Biological Control 52: 91-95. https://doi.org/10.1016/j. biocontrol.2009.07.016

Tooley, J. A. \& Brust, G. E. (2002): Weed seed predation by carabid beetles. In: Holland, J. M. (ed.): The agroecology of carabid beetles. - Intercept, Andover, Hampshire, 356 pp.

Tooley, J. A., Froud-Williams, R. J., Boatman, N. D. \& Holland, J. M. (1999): Laboratory studies of weed seed predation by carabid beetles. - Brighton Conference: Weeds, Vols 1-3, 571-572. pp.

WALL, S. B. VAN DER (1998): Foraging success of granivorous rodents: Effects of variation in seed and soil water on olfaction. - Ecology 79: 233-241. https://doi.org/10.1890/00129658(1998)079[0233:FSOGRE]2.0.CO;2 
Widmer, T. L., Guermache, F., Dolgovskaia, M. Y. \& Reznik, S. Y. (2007): Enhanced growth and seed properties in introduced vs. native populations of yellow starthistle (Centaurea soistitialis). - Weed Science 55: 465-473. https://doi.org/10.1614/ws-06-211r.1

Westerman P. R., Wes J. S., Kropff M. J. \& Werf, W. van der (2003): Annual losses of weed seeds due predation in organic fields. - Journal of Applied Ecology 40: 824-836. https:// doi.org/10.1046/j.1365-2664.2003.00850.x

Received May 4, 2020, accepted November 5, 2020, published December 28, 2020 